\title{
ANALISIS KEPUASAN NASABAH TERHADAP PELAYANAN FRONTLINER BANK X KANTOR CABANG KHUSUS SUDIRMAN
}

\author{
ANALYSIS OF FRONTLINER CUSTOMER SERVICE SATISFACTION OF \\ BANK X OFFICIAL BRANCH OF SUDIRMAN
}

\author{
Andani Fauzita Vidyandari ${ }^{*}$, , Matunun Parulian Hutagaol ${ }^{* *}$, dan Joko Affandi ${ }^{* * *}$ ) \\ *) Sekolah Bisnis, IPB University \\ Jl. Pajajaran Bogor 16151 \\ ${ }^{* *}$ Departement Ilmu Ekonomi, Fakultas Ekonomi dan Manajemen, IPB University \\ Jl. Agatis Kampus IPB Darmaga, Bogor 16680 \\ $\left.{ }^{* * *}\right)$ PPM Manajemen \\ Jl. Menteng Raya No. 9 - 19, Menteng, Jakarta Pusat Jakarta 10340
}

\begin{abstract}
Customer satisfaction is the key to a service company's success, especially in the banking industry with its increasingly fierce competition. Customer satisfaction is measured by staff services, where interaction between customers and staff is the key. Unsatisfactory frontline staff's (forntliner) services can lower the bank's image in customers' eyes. This study aimed to analyze customer satisfaction with the frontliner's services at Bank-X official branch of Sudirman. The data were collected using a questionnaire with a convenience sampling technique to select the respondents. The analysis method used was SERVQUAL method and gap analysis where customer satisfaction would be known from the difference between customer perceptions of received service with customer expectations. The results showed that customer expectations were higher than perceptions of the frontliner's services, but that did not mean that Bank X's frontliner's services were of poor quality. Respondents who chose Bank X as the main bank compared to other banks and the Cartesius diagram results showed no need to improve service attributes, showing that the customer's opinion on the service is already good. The majority of the respondents' characteristics were office workers, highly educated, and earn more than 5 million rupiahs would certainly have high aspirations. Therefore their expectations of service would also be higher. What needs to be done by Bank X's frontliners is to maintain the quality of existing services and cut down the waiting time for customers by installing the self-service system.
\end{abstract}

Keywords: customer satisfaction, frontliner, gap analysis, Importance Performance Analysis, SERVQUAL

\begin{abstract}
Abstrak: Kepuasan pelanggan adalah kunci dari kesuksesan suatu perusahaan jasa, terutama di industri perbankan yang semakin hari semakin ketat persaingannya. Kepuasan pelanggan diukur dari pelayanan staf dimana interaksi nasabah dengan staf menjadi kunci pelayanan. Pelayanan frontliner yang tidak memuaskan dapat menurunkan citra bank di mata nasabah. Tujuan penelitian ini adalah untuk menganalisa tingkat kepuasan nasabah terhadap pelayanan staf frontliner di Bank X kantor cabang khusus Sudirman. Metode pengumpulan data menggunakan kuesioner dengan teknik convenience sampling untuk memilih responden, dan metode analisis yang dipakai adalah metode SERVQUAL dan analisa gap dimana kepuasan nasabah akan diketahui dari selisih persepsi nasabah atas pelayanan yang diterima dengan ekspektasi nasabah. Hasil penelitian menunjukkan harapan nasabah lebih tinggi dari persepsi terhadap pelayanan frontliner. Namun, bukan berarti pelayanan frontliner Bank X berkualitas rendah. Jawaban responden yang lebih memilih Bank X sebagai bank utama dibanding bank lain, serta hasil diagram kartesius yang menunjukkan tidak perlu dilakukan banyak pembenahan atribut pelayanan menunjukkan bahwa opini nasabah terhadap pelayanan sudah baik. Mayoritas karakteristik responden yang berprofesi pekerja swasta, berpendidikan tinggi serta berpenghasilan di atas 5 juta rupiah tentu memiliki aspirasi tinggi sehingga eskpektasi terhadap pelayanan frontliner juga lebih besar. Hal yang perlu dilakukan pihak frontliner Bank X adalah mempertahankan kualitas pelayanan yang telah ada dan mempercepat waktu pelayanan dengan cara instalasi sistem self-service.
\end{abstract}

Kata kunci: kepuasan nasabah, frontliner, analisis gap, analisis tingkat kepentingan kinerja, servqual

${ }^{1}$ Alamat korespondensi:

Email: andani.fauzita@gmail.com 


\section{PENDAHULUAN}

Perbankan adalah salah satu industri dengan jumlah perusahaan yang banyak di Indonesia. Karena semua bank diberikan kesempatan bersaing bebas dalam pemasaran produk maupun pelayanan yang ditawarkan, perlu diterapkan strategi yang mampu memberikan suatu bank keunggulan. Salah satu strategi itu adalah dengan memberikan pelayanan yang bermutu (Kotler, 2011). Nasabah dengan tingkat kepuasan rendah dengan mudah beralih ke perusahaan lain yang menawarkan pelayanan yang lebih baik, sedangkan nasabah yang puas cenderung lebih setia terhadap suatu perusahaan. Grönroos (2007) mengatakan strategi pelayanan selain mampu membedakan suatu perusahaan dengan yang lain, juga dapat menghindarkan pesaing mencampur tangani hubungan dengan nasabah.

Pelayanan adalah setiap kegiatan atau manfaat yang ditawarkan oleh suatu pihak pada pihak lain dan pada dasarnya tidak berwujud, juga tidak menghasilkan kepemilikan atas sesuatu (Kotler, 2011). Interaksi antara pemberi jasa dengan klien sering kali mengharuskan klien untuk berpartisipasi dengan organisasi jasa; klien juga harus menyesuaikan diri dengan sistem dan rutinitas operatif maupun administratif di organisasi dan sering kali harus menggunakan sumber daya teknologi seperti mesin teller. Jika interaksi-interaksi ini dianggap terlalu sulit atau tidak nyaman, kualitas pelayanan organisasi bisa jatuh di mata klien (Grönroos, 2007).

Interaksi sebagai kunci dari pemasaran jasa terjadi secara konstan di bank, terutama di bagian frontline. Frontliner adalah istilah umum untuk customer service dan teller yang berinteraksi langsung dengan nasabah secara konstan. Pelayanan yang kurang baik atau tidak sesuai dengan ekspektasi nasabah akan berpengaruh besar terhadap citra bank. Dari frontliner juga nasabah dapat tertarik untuk menggunakan produk dan fasilitas yang ditawarkan oleh bank. Salah satu parameter untu melihat budaya pelayanan dari suatu perusahaan adalah dari pelayanan yang diberikan oleh frontliner.

Bank X sebagai bank milik pemerintah dengan jumlah nasabah aktif terbanyak di Indonesia harus senantiasa menghadapi situasi yang kompetitif di industri perbankan dan meningkatkan pelayanannya dalam menyiasati persaingan antara bank lain. Dari laporan mengenai fenomena customer switching behavior nasabah tabungan Bank X, customer switching menjadi masalah yang dihadapi Bank X. Pada kuartal 1 tahun 2017, sebanyak 625.000 nasabah telah berpindah MFI ke bank lain. MFI atau Main Financial Insitution adalah lembaga keuangan dengan penggunaan ataupun share paling tinggi yang dimiliki oleh nasabah apabila nasabah tersebut memiliki lebih dari satu lembaga keuangan.

Terdapat dua faktor yang memengaruhi perpindahan MFI nasabah tabungan Bank X, yaitu faktor pendorong (Push) atau sisi pengalaman negatif dari pihak Bank $\mathrm{X}$, dan faktor penarik (pull), yaitu sisi tawaran atau pengalaman positif dari bank lain. Perbandingan persentase antara faktor pendorong dan penarik secara umum terbagi rata ( $51,1 \%$ dengan $48,9 \%$ ), tetapi sedikit lebih condong ke faktor pendorong. Faktor pendorong yang paling umum memengaruhi nasabah menurut laporan ini adalah 1) Antrian di Teller atau Customer Service (CS), 2) Mesin ATM yang sering offline, dan 3) Layanan teller atau CS yang sering memakan waktu lama. Persentase terbesar yang memengaruhi nasabah switching dari segi ini dipegang oleh aspek proses (22\%), baik pelayanan maupun kinerja ATM (Nielsen, 2017).

Selain dari dua faktor tersebut, hasil wawancara dari tim research and development Bank X menunjukkan perpindahan MFI nasabah tabungan Bank $\mathrm{X}$ juga dipengaruhi dari sisi touchpoint. Touchpoint adalah setiap momen nasabah melakukan kontak dengan brand Bank X, meliputi penggunaan ATM, kantor cabang, produk tabungan, marketing dan promosi, interaksi dengan staff dan lain-lain. Touchpoint tertinggi dipegang oleh ATM kemudian kantor cabang, sehingga dapat disimpulkan efek paling besar dalam hal perpindahan MFI adalah dari sisi jaringan dan lokasi ATM, serta layanan dan lokasi unit kerja.

Dapat disimpulkan bahwa alasan nasabah switching adalah: (1) layanan yang kurang cepat dan level pelayanan yang masih rendah, serta durasi transaksi per nasabah yang terlalu lama dan antrian yang terlalu Panjang, (2) kekurangan jumlah SDM untuk menangani jumlah nasabah yang besar juga mengakibatkan antrian yang Panjang, (3) pegawai yang tidak ramah membuat sebagian nasabah beralih ke bank lain meskipun menempuh jarak yang jauh, (4) sistem yang kerap bermasalah sehingga menghambat kelancaran transaksi seperti ATM offline, dan (5) Terbatasnya mesin ATM yang dapat melakukan transaksi setor tunai dibandingkan bank lain. 
Bank X sebagai BUMN memang memiliki jumlah nasabah yang banyak di skala nasional dikarenakan reputasinya sebagai bank pemerintah yang terpercaya namun kenyataannya image ini tidak cukup kuat dalam mempertahankan loyalitas nasabah terhadap Bank X, terlihat dari intensi nasabah untuk menutup rekening masih cukup besar, yaitu nasabah non aktif Bank X sebanyak 54\%, Simpedes sebanyak 47\%, dan non-MFI sebanyak $20 \%$.

Jumlah ini menunjukkan adanya potensi Bank X kehilangan nasabah MFI yang lebih besar lagi kedepannya (Morgan, 2017). Keadaan industri perbankan yang memiliki persaingan tinggi menjadikan kualitas pelayanan sebagai salah satu strategi yang dapat diterapkan Bank X demi menciptakan loyalitas nasabah melalui pengalaman positif. Loyalitas ini dapat dibentuk dengan pengalaman interaksi nasabah yang positif dengan Bank X. Sebagai salah satu pemegang touchpoint tertinggi dari suatu bank, staf frontliner dituntut untuk memiliki kemampuan dalam melayani dan membantu nasabah, memiliki kecepatan transaksi yang sesuai dengan ekspektasi serta mampu memberikan solusi atas permasalahan yang dihadapi nasabah dengan akurat. Kondisi tersebut menjadi hal krusial dalam penilaian pelayanan di mata nasabah dan menentukan loyalitas nasabah atas perusahaan.

Frontliner adalah barisan bagian depan yang melakukan kontak langsung dengan tamu atau nasabah (Tarmoezi et al. 2000). Penempatan staf di bagian ini harus selektif karena merekalah yang menciptakan kesan pertama bagi nasabah. Dalam dunia perbankan, frontliner adalah barisan paling depan yang berperan dalam aktivitas utama di sebuah bank dan merupakan staf yang langsung berhubungan dengan nasabah (guest contact). Penempatan staf frontliner akan menciptakan kesan pertama yang baik atau buruk terhadap suatu bank. Frontliner terdiri dari customer service (CS) dan teller namun dengan berkembangnya industri perbankan, Satuan Pengamanan atau Security yang berada dalam area banking hall dikategorikan sebagai frontliner.

Hutapea dan Thoha (2008) memberikan contoh kompetensi perilaku yang berhubungan dengan pelanggan yang harus dimiliki oleh petugas frontliner yaitu, (1) melakukan komunikasi dengan baik dan jelas kepada pelanggan pada saat merespon pencarian informasi, permintaan dan keluhan serta menghubungkan semua aktivitas pekerjaan dengan kebutuhan pelanggan, (2) mengenali masalah pelanggan dan mengusulkan alternatif pemecahan masalah, (3) menyampaikan dan mendistribusikan informasi terkini kepada nasabah serta menindaklanjuti perkembangan komunikasi, dan (4) mempersiapkan diri untuk siap membantu pelanggan kapanpun dibutuhkan.

Dalam peraturan Bank $\mathrm{X}$ kantor cabang khusus Sudirman seluruh bagian frontliner diwajibkan mentaati standar dan prosedur layanan yang telah ditetapkan. Dalam melaksanakan tugasnya frontliner dituntut untuk bersikap dan berperilaku sepenuh hati dalam melayani sehingga nasabah terkesan dengan layanan yang diberikan. Sikap-sikap yang dituntut misalnya berdiri, tersenyum, dan mengucapkan salam ketika menyambut nasabah, menawarkan bantuan dengan ramah kepada nasabah, memanggil nasabah dengan namanya, serta mengucapkan terima kasih ketika selesai melayani.

Metode pengukuran kualitas pelayanan yang sering digunakan adalah metode Servqual dan metode importance performance analysis (IPA). Servqual mengukur kepuasan pelayanan dengan mencari selisih atau gap antara persepsi nasabah atas pelayanan yang diterima, dengan harapan nasabah atas pelayanan. Jika persepsi layanan lebih tinggi dari harapan nasabah, maka pelayanan dianggap memuaskan. Jika persepsi lebih rendah dari harapan nasabah, maka pelayanan dianggap belum memuaskan. Terdapat lima dimensi pelayanan menurut Servqual, yaitu (1) tangibles atau berwujud; (2) reliability atau keandalan; (3) responsiveness atau daya tanggap; (4) assurance atau jaminan, dan (5) empathy.

Metode IPA adalah metode pengukuran kepuasan pelanggan atau pengguna yang menghasilkan identifikasi area yang perlu dikembangkan dengan mudah dan fungsional (Miranda et al. 2010). Dengan memetakan atribut-atribut pelayanan yang telah diukur berdasarkan persepsi nasabah di diagram kartesius puas penting, maka akan didapatkan tingkat kepentingan dan tingkat kinerja tiap atribut pelayanan. Sumbu Y (vertikal) di diagram menunjukkan tingkat kepentingan pelayanan dan sumbu $\mathrm{X}$ (horisontal) menunjukkan tingkat kinerjanya. Kedua sumbu ini membagi diagram menjadi empat kuadran yang meggambarkan urutan kepentingan dan kinerja atribut pelayanan.

Dalam jurnal Adiningsih et al. (2015), Syukri (2014) dan Baroroh (2014), lima dimensi Servqual (responsiveness, tangibles, reliability, assurance 
dan empathy) digunakan sebagai indikator pengukur kepuasan pelanggan. Dalam pembuatan kuesioner kualitas pelayanan, skala likert 5 poin digunakan oleh Wijaya et al.(2017) dimana skala 1 bernilai "sangat tidak setuju" hingga skala 5 yang bernilai "sangat setuju". Paramitasari (2016) menggunakan metode Servqual untuk mengukur kualitas pelayanan Bagian Penerimaan Mahasiswa Baru (PMB) Institut Informatika dan Bisnis Darmajaya. Pengukuran penilaian pelanggan atau calon mahasiswa dikumpulkan dengan metode survei dan metode analisis deskriptif digunakan untuk mengukur karakteristik responden. Hasil penelitian menujukkan bahwa terdapat kesenjangan dalam semua dimensi kualitas PMB dimana kesenjangan tertinggi dipegang oleh dimensi reliability. Pratiwi et al. (2013) dan Phiri dan Mcwabe (2013) menggunakan satu jenis kesenjangan atau gap dari metode Servqual, yaitu gap 5 (hubungan antara layanan yang diberikan dengan apa yang diharapkan oleh konsumen). Hasil penelitian Pratiwi et al. menunjukkan bahwa gap pada seluruh dimensi pelayanan Farmasi Rawat Jalan Rumah Sakit $\mathrm{X}$ masih bernilai negatif, yang berarti pasien belum puas dengan kinerja rumah sakit yang diterima. Dengan metode yang sama, Phiri dan Mcwabe (2013) juga mendapatkan hasil penelitian yang menunjukkan bahwa ekspektasi pelanggan terhadap kualitas pelayanan retail lebih tinggi dari yang diantisipasi, dilihat dari nilai gap 5 yang bernilai negatif. Namun hasil gap yang negatif tidak selalu berarti kualitas pelayanan sangat rendah atau buruk. Windyani et al. (2011) dalam analisis kepuasan masyarakat terhadap pelayanan Disdukcapil mendapatkan hasil gap yang negatif tetapi hasil analisis indeks kepuasan menunjukkan masyarakat sudah puas. Hal ini menunjukkan bahwa pelanggan senantiasa mengharapkan pelayanan yang melampaui ekspektasi mereka, walaupun kualitas pelayanan sudah dianggap bagus atau standar.

Selain metode Servqual, metode IPA juga sering digunakan untuk mengukur kualitas pelayanan. Wong et al. (2011) menggunakan metode IPA untuk mengevaluasi keuntungan proyek e-government pemerintah Jepang. Metode ini dipilih karena penggunaan indikator tingkat kepentingan dari persepsi pelanggan, yang memungkinkan peneliti mendapatkan gambaran opini pelanggan yang lebih akurat karena tidak hanya bertumpu di indikator kinerja saja. Penggunaan diagram juga membuat hasil pengukuran lebih mudah dimengerti dan lebih cepat untuk melihat area prioritas pengembangan kualitas.
Sofyan (2016) menggunakan metode IPA untuk menganalisis kepuasan masyarakat terhadap proyek pengendalian banjir perkotaan di Kabupaten Mojokerto. Dengan memetakan butir pernyataan di kuadran diagram kartesius sesuai dengan tingkat kepentingan dan tingkat kinerjanya, disimpulkan bahwa proyek pengendalian banjir belum efektif dan masih perlu dilakukan sosialisasi terhadap masyarakat yang lebih mendalam. Ong et al. (2014) menggunakan pemetaan dalam diagram kartesius untuk melihat atribut pelayanan SBU Laboratory Cibitung PT Sucofindo apa saja yang harus menjadi prioritas pembenahan. Atribut pelayanan di Kuadran A (Underact) menjadi prioritas pembenahan, karena tingkat kinerja atribut masih dianggap rendah walaupun dianggap penting oleh pelanggan. Despriyatmoko et al. (2016) dalam analisisnya tentang tingkat kepuasan pelayanan pemeliharaan data pendaftaran tanah di Kabupaten Bogor mendapatkan hasil bahwa masyarakat sudah puas karena atribut pelayanan yang sebagian besar terfokus di kuadran B (Maintain), dimana kinerja dan kepentingan pelayanan sudah tinggi dan sesuai sehingga kualitasnya perlu dipertahankan. Wiramanggala et al. (2017) juga mendapatkan bentuk diagram kartesius dimana atribut pelayanan terfokus di kuadran B (Maintain) dan kuadran C (Lower Priority), yaitu kuadran yang menunjukkan atribut dengan tingkat kepentingan dan tingkat kinerja yang rendah. Karena tingkat kepentingan sewaktuwaktu dapat berubah maka atribut di kuadran ini tetap perlu diwaspadai.

Dari penjelasan sebelumnya, dapat dirumuskan tujuan penelitian yaitu untuk mengetahui kualitas pelayanan staf frontliner Bank X kantor cabang khusus Sudirman, mengetahui bagian pelayanan mana yang harus diprioritaskan untuk perkembangan atau pembenahan, serta menyarankan strategi yang dapat diterapkan perusahaan untuk menyempurnakan pelayanan frontliner.

\section{METODE PENELITIAN}

Lokasi penelitian dilakukan di kantor cabang khusus Bank X di Jalan Jendral Sudirman, Bendungan Hilir, Jakarta Pusat. Pengumpulan data dilakukan sejak bulan Oktober sampai November 2019. Penelitian ini bersifat deskriptif dengan data primer diambil menggunakan metode survei berbentuk kuesioner. Responden kuesioner merupakan nasabah yang sudah bertransaksi maupun sedang menunggu di banking hall Kantor 
cabang khusus Sudirman. Jumlah sampel ditentukan dengan teknik convenience sampling (Sekaran dan Bougie, 2013) untuk menyesuaikan dengan kondisi nasabah yang silih berganti keluar masuk area banking hall.

Metode analisis yang digunakan adalah metode Servqual (analisis gap) dan metode IPA. Dari lima dimensi pelayanan Servqual, disusun 19 butir pernyataan yang mencakup semua dimensi pelayanan (Tabel 1). Baik kuesioner Servqual maupun kuesioner IPA menggunakan 19 butir pernyataan ini. Skala yang digunakan dalam kedua kuesioner adalah skala likert 5 poin. Malhotra dan Dash (2016) dan Hair (2010) menyatakan apabila jumlah populasi tidak diketahui secara pasti, dalam hal ini karena nasabah silih berganti keluar dari banking hall, maka jumlah sampel harus berukuran minimum lima kali dari jumlah indikator. Berdasarkan teori ini maka jumlah sampel yang didapat adalah 19 butir x $5=95$ orang. Untuk keakuratan survei kuesioner, jumlah sampel ditambah menjadi 130 orang.

Kepuasan nasabah merupakan indikasi kualitas pelayanan suatu bank. Sebagai bagian bank dengan interaksi tinggi dengan nasabah, frontliner yang mampu memberikan pelayanan yang berkualitas akan menjadi keunggulan suatu bank. Dengan melihat hasil selisih antara persepsi dan harapan nasabah terhadap pelayanan frontliner, akan didapatkan tingkat kualitas pelayanan frontliner Bank $\mathrm{X}$ kantor cabang khusus Sudirman. Dari penjelasan tersebut, dapat diasumsikan dua kemungkinan hasil penelitian yaitu sebagai berikut:

1. Persepsi nasabah lebih tinggi dari harapan $\rightarrow$ Kualitas pelayanan sudah memuaskan

2. Harapan nasabah lebih tinggi dari persepsi $\rightarrow$ Kualitas pelayanan belum memuaskan

Tabel 1. Butir pernyataan Servqual

\begin{tabular}{|c|c|c|c|c|c|}
\hline \multirow[b]{2}{*}{ Butir Pernyataan per dimensi } & \multicolumn{2}{|c|}{ Persepsi Pelayanan } & \multicolumn{2}{|c|}{ Harapan Pelayanan } & \multirow[b]{2}{*}{$\begin{array}{c}\text { Nilai Gap } \\
\text { (Kesenjangan) }\end{array}$} \\
\hline & Pembobotan & $\begin{array}{l}\text { Rata-rata } \\
\text { Persepsi }\end{array}$ & Pembobotan & $\begin{array}{l}\text { Rata-rata } \\
\text { Harapan }\end{array}$ & \\
\hline B1 & 619 & 4,76 & 630 & 4,84 & $-0,08$ \\
\hline B2 & 619 & 4,76 & 633 & 4,86 & $-0,10$ \\
\hline B3 & 560 & 4,30 & 635 & 4,88 & $-0,58$ \\
\hline B4 & 521 & 4,00 & 520 & 4,00 & $\mathbf{0 , 0 0}$ \\
\hline B5 & 520 & 4,00 & 521 & 4,00 & $\mathbf{0 , 0 0}$ \\
\hline \multicolumn{2}{|l|}{ Rata-rata Tangibles } & 4,36 & & 4,51 & $-0,15$ \\
\hline K6 & 576 & 4,43 & 629 & 4,83 & $-0,40$ \\
\hline K7 & 553 & 4,25 & 621 & 4,77 & $-0,52$ \\
\hline K8 & 540 & 4,15 & 586 & 4,50 & $-0,35$ \\
\hline K9 & 520 & 4,00 & 521 & 4,00 & $\mathbf{0 , 0 0}$ \\
\hline $\mathrm{K} 10$ & 517 & 3,97 & 523 & 4,02 & $-0,05$ \\
\hline \multicolumn{2}{|l|}{ Rata-rata Reliability } & 4,16 & & 4,24 & $-0,26$ \\
\hline D11 & 570 & 4,38 & 624 & 4,80 & $-0,42$ \\
\hline D12 & 521 & 4,00 & 524 & 4,03 & $-\mathbf{0 , 0 3}$ \\
\hline \multicolumn{2}{|l|}{ Rata-rata Responsiveness } & 4,19 & & 4,41 & $-0,22$ \\
\hline J13 & 574 & 4,42 & 621 & 4,77 & $-0,35$ \\
\hline $\mathrm{J} 14$ & 532 & 4,09 & 532 & 4,09 & $\mathbf{0 , 0 0}$ \\
\hline $\mathrm{J} 15$ & 524 & 4,03 & 519 & 3,99 & 0,04 \\
\hline $\mathrm{J} 16$ & 522 & 4,01 & 520 & 4,00 & $\mathbf{0 , 0 1}$ \\
\hline \multicolumn{2}{|l|}{ Rata-rata Assurance } & 4,13 & & 4,21 & $-0,08$ \\
\hline E17 & 582 & 4,47 & 626 & 4,81 & $-0,34$ \\
\hline E18 & 566 & 4,35 & 590 & 4,53 & $-0,18$ \\
\hline E19 & 518 & 3,98 & 515 & 3,96 & 0,02 \\
\hline Rata-rata Empathy & & 4,26 & & 4,43 & $-0,17$ \\
\hline
\end{tabular}


Strategi bank yang menekankan terhadap kualitas pelayanan yang bermutu dapat membantu Bank $\mathrm{X}$ dalam menjaga keberlanjutan nasabah ataupun menarik nasabah baru. Frontliner sebagai bagian yang konstan berinteraksi dan melayani nasabah merupakan parameter yang dapat digunakan untuk kualitas pelayanan perusahaan. Untuk mengetahui kualitas pelayanan, perlu diketahui kepuasan nasabah terdahulu yang didapat dari selisih persepsi dan harapan nasabah terhadap pelayanan (analisis gap). Selanjutnya melalui pemetaan atribut-atribut pelayanan di diagram kartesius berdasarkan opini nasabah (analisis IPA), akan didapatkan bagian pelayanan mana saja yang perlu dibenahi atau dipertahankan. Kerangka pemikiran dapat dilihat di Gambar 1.

\section{HASIL}

\section{Karakteristik responden}

Hasil kuesioner menunjukkan bahwa mayoritas responden adalah laki-laki (56,2\%) dan Usia responden didominasi oleh kelompok usia 36-45 tahun. Mayoritas pendidikan terakhir responden adalah sarjana $(65,4 \%)$ dengan jenis pekerjaan yang paling dominan pegawai swasta $(60,8 \%)$ dan kelompok penghasilan terbanyak adalah penghasilan $>5$ juta rupiah $(82,3 \%)$. Dua profil responden ini sesuai dengan kelompok frekuensi kunjungan responden terbanyak yaitu sebulan sekali (54,6\%). Walau pelayanan e-banking semakin sering digunakan untuk transaksi, lokasi bank yang mudah dijangkau dan dekat dengan perkantoran mendorong nasabah untuk mengunjungi kantor frontline secara langsung, kemungkinan karena merasa transaksi lebih aman jika dilayani langsung.

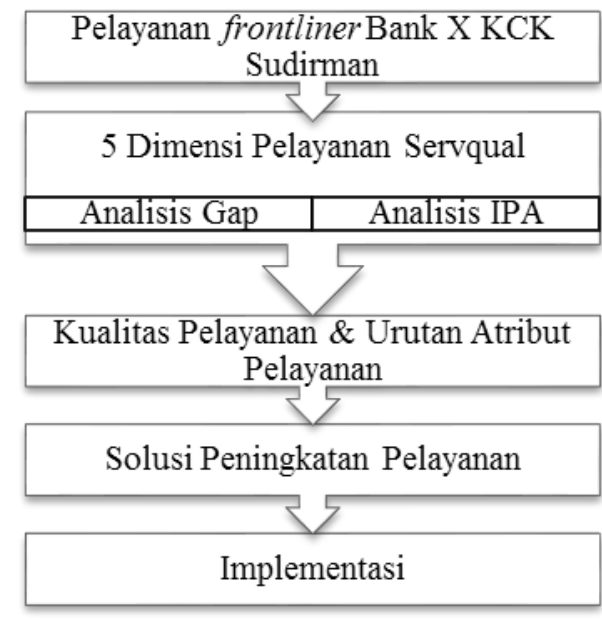

Gambar 1. Kerangka pemikiran penelitian
Alasan sebagian besar responden memilih Bank $\mathrm{X}$ adalah "karena reputasinya" (71,5\%) dengan perkenalan responden terhadap Bank X paling banyak dari iklan atau marketing (74,6\%). Sebagian besar responden mempunyai rekening di bank lain $(75,4 \%)$ dan jenis bank lain yang paling banyak dipilih adalah bank swasta nasional $(45,4 \%)$. Seluruh responden yang memiliki rekening di bank lain menyatakan lebih memilih memakai Bank X sebagai bank utama karena "reputasinya" (50,8\%).

\section{Kualitas Pelayanan Staf Frontliner}

Kualitas pelayanan didapat dari selisih atau kesenjangan antara persepsi dan harapan nasabah atas pelayanan yang didapat. Secara keseluruhan, hasil kesenjangan (gap) bernilai negatif di seluruh dimensi. Hal ini menunjukkan bahwa harapan nasabah masih lebih tinggi dibandingkan persepsi nasabah atas pelayanan frontliner Bank X kantor cabang khusus Sudirman. Skor persepsi dan skor harapan pelayanan dapat dilihat di Tabel 2.

Dimensi dengan nilai gap terbesar adalah dimensi reliability (keandalan) dengan nilai sebesar -0,26. Dimensi ini mencakup kemampuan staf frontliner dalam memberikan pelayanan yang tanggap, cepat, akurat kepada nasabah tanpa dimintai bantuan, serta penyampaian informasi layanan dan produk bank dari staf yang jelas dan mendetail. Dimensi kedua dengan nilai gap terbesar adalah dimensi responsiveness (daya tanggap) dengan nilai sebesar $-0,22$. Dimensi ini mencakup kemampuan staf frontliner dalam memberikan pelayanan yang akurat dan adil kepada nasabah tanpa membeda-bedakan status atau latar belakang. Dimensi ketiga dengan nilai gap terbesar adalah dimensi empathy dengan nilai sebesar $-0,17$. Dimensi ini mencakup kemampuan staf frontliner dalam memahami kebutuhan nasabah dan tidak adanya antrian panjang di bank sehingga nasabah tidak menghabiskan waktu dan letih menunggu pelayanan. Dimensi keempat dengan nilai gap terbesar adalah dimensi tangibles (berwujud) dengan nilai $-0,15$. Dimensi ini mencakup kebersihan dan kenyamanan bank, penampilan staf frontliner yang rapi dan menarik, fasilitas ATM selalu berjalan dengan baik, tempat parkir yang luas dan aman karena selalu dijaga oleh petugas. Terakhir, dimensi dengan nilai gap terkecil adalah dimensi assurance (jaminan) dengan nilai gap sebesar $-0,08$. Dimensi ini mencakup kemampuan staffrontliner dalam memberikan solusi atau saran yang tepat untuk 
permasalahan nasabah, membuat nasabah merasa aman mempercayakan dana kepada staf frontliner, tindakan dan ucapan staf frontliner mampu menumbuhkan rasa percaya nasabah, serta konsistensi pelayanan staf untuk selalu sopan dalam melayani.

Meskipun nilai gap kelima dimensi pelayanan bernilai negatif, nilai negatif tiap dimensi sangatlah kecil. Setiap hasil selisih tidak melebihi minus satu (-1). Hal ini menunjukkan bahwa perbedaan harapan nasabah dengan persepsi nasabah atas pelayanan staf frontliner Bank X kantor cabang khusus Sudirman sangatlah kecil dan tidak signifikan. Melihat opini nasabah terhadap Bank X Kantor cabang khusus Sudirman yang sangat positif di bagian karakteristik responden, hal ini menunjukkan bahwa kualitas pelayanan frontliner sebetulmnya sudah memuaskan namun nasabah mengharapkan nilai lebih.

\section{Urutan Prioritas Pelayanan}

Pemetaan atribut-atribut pelayanan dilakukan berdasarkan penilaian nasabah atas tingkat kepentingan dan tingkat kinerja pelayanan staf frontliner. Dari pemetaan tersebut, akan didapatkan atribut pelayanan mana yang harus menjadi prioritas perbaikan, dipertahankan atau dikurangi kinerjanya karena berlebihan. Dilihat dalam diagram kartesius (Gambar 2) bahwa sebagian besar atribut pelayanan terkonsentrasi di beberapa kuadran saja.

Tabel 2. Hasil selisih atau gap analysis Servqual

\begin{tabular}{|c|c|c|c|c|c|}
\hline \multirow[b]{2}{*}{ Butir Pernyataan per dimensi } & \multicolumn{2}{|c|}{ Persepsi Pelayanan } & \multicolumn{2}{|c|}{ Harapan Pelayanan } & \multirow[b]{2}{*}{$\begin{array}{c}\text { Nilai Gap } \\
\text { (Kesenjangan) }\end{array}$} \\
\hline & Pembobotan & $\begin{array}{l}\text { Rata-rata } \\
\text { Persepsi }\end{array}$ & Pembobotan & $\begin{array}{l}\text { Rata-rata } \\
\text { Harapan }\end{array}$ & \\
\hline B1 & 619 & 4,76 & 630 & 4,84 & $-0,08$ \\
\hline B2 & 619 & 4,76 & 633 & 4,86 & $-0,10$ \\
\hline B3 & 560 & 4,30 & 635 & 4,88 & $-0,58$ \\
\hline B4 & 521 & 4,00 & 520 & 4,00 & $\mathbf{0 , 0 0}$ \\
\hline B5 & 520 & 4,00 & 521 & 4,00 & $\mathbf{0 , 0 0}$ \\
\hline \multicolumn{2}{|l|}{ Rata-rata Tangibles } & 4,36 & & 4,51 & $-0,15$ \\
\hline K6 & 576 & 4,43 & 629 & 4,83 & $-0,40$ \\
\hline K7 & 553 & 4,25 & 621 & 4,77 & $-0,52$ \\
\hline K8 & 540 & 4,15 & 586 & 4,50 & $-0,35$ \\
\hline K9 & 520 & 4,00 & 521 & 4,00 & 0,00 \\
\hline K10 & 517 & 3,97 & 523 & 4,02 & $-0,05$ \\
\hline \multicolumn{2}{|l|}{ Rata-rata Reliability } & 4,16 & & 4,24 & $-0,26$ \\
\hline D11 & 570 & 4,38 & 624 & 4,80 & $-0,42$ \\
\hline D12 & 521 & 4,00 & 524 & 4,03 & $-0,03$ \\
\hline \multicolumn{2}{|l|}{ Rata-rata Responsiveness } & 4,19 & & 4,41 & $-0,22$ \\
\hline J13 & 574 & 4,42 & 621 & 4,77 & $-0,35$ \\
\hline $\mathrm{J} 14$ & 532 & 4,09 & 532 & 4,09 & $\mathbf{0 , 0 0}$ \\
\hline $\mathrm{J} 15$ & 524 & 4,03 & 519 & 3,99 & 0,04 \\
\hline $\mathrm{J} 16$ & 522 & 4,01 & 520 & 4,00 & $\mathbf{0 , 0 1}$ \\
\hline \multicolumn{2}{|l|}{ Rata-rata Assurance } & 4,13 & & 4,21 & $-0,08$ \\
\hline E17 & 582 & 4,47 & 626 & 4,81 & $-0,34$ \\
\hline E18 & 566 & 4,35 & 590 & 4,53 & $-0,18$ \\
\hline E19 & 518 & 3,98 & 515 & 3,96 & 0,02 \\
\hline Rata-rata Empathy & & 4,26 & & 4,43 & $-0,17$ \\
\hline
\end{tabular}




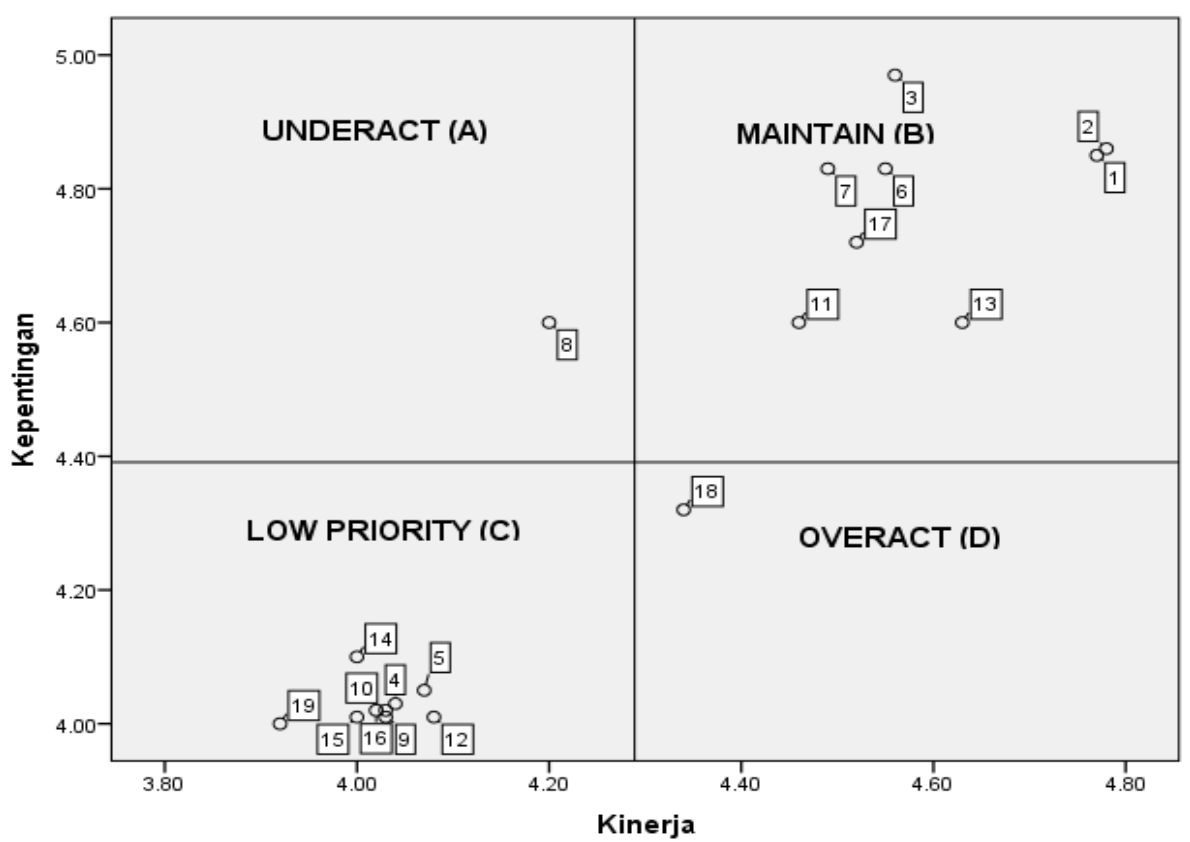

Gambar 2. diagram Kartesius tingkat kepentingan dan tingkat kinerja atribut pelayanan

\section{Kuadran A (underact)}

Kuadran ini berisi atribut yang dianggap cukup penting namun kinerjanya masih dianggap rendah. Hanya ada satu atribut yang masuk ke kuadran ini yaitu kuadran "kecepatan staf dalam memberikan pelayanan". Hal ini menunjukkan bahwa atribut pelayanan ini harus menjadi prioritas pembenahan oleh perusahaan.

\section{Kuadran B (maintain)}

Kuadran ini menunjukkan atribut yang perlu dipertahankan prestasinya karena tingkat kepentingan dan kinerjanya sudah sesuai dengan keinginan nasabah. Atribut yang termasuk kuadran B cukup banyak jumlahnya yaitu "kebersihan dan kenyamanan bank", "penampilan staf frontliner", "kinerja fasilitas ATM di bank", "ketanggapan staf dalam membantu nasabah yang kesulitan", "kesediaan staf dalam membantu nasabah tanpa dimintai bantuan", "keakuratan pelayanan nasabah dari staf", "pemberian solusi atau saran yang tepat atas masalah nasbah", dan "ketepatan staf dalam memahami kebutuhan nasabah.”

\section{Kuadran C (low priority)}

Kuadran ini berisi atribut pelayanan yang dianggap tidak terlalu penting dan tingkatkinerjanya biasa saja sehingga tidak perlu menjadi prioritas pembenahan. Atribut yang termasuk dalam kuadran ini adalah "layanan staf frontliner yang profesional", "penyampaian informasi yang detail", "memberikan rasa aman pada nasabah", "tindakan dan ucapan staf yang dapat dipercaya", "pelayanan staf frontliner yang sopan", "keamanan tempat parkir, " kejelasan penyampaian informasi tentang bank dari staf frontliner", dan "antrian yang tidak panjang di kantor.

\section{Kuadran D (overact)}

Kuadran ini menunjukkan atribut pelayanan yang dianggap tidak terlalu penting bagi nasabah namun mempunyai kinerja yang berlebihan. Hanya ada satu atribut yang masuk di kategori ini yaitu "antrian yang tidak panjang di kantor". Perusahaan perlu mengurangi anggaran dan waktu yang dialokasikan untuk atribut pelayanan ini agar dapat mencurahkan tenaga ke atribut lain yang lebih penting.

\section{Implikasi Manajerial}

Penelitian ini bertujuan untuk menganalisis kualitas pelayanan frontliner Bank X kantor cabang khusus Sudirman serta menganalisis bagian pelayanan frontliner mana yang harus diprioritaskan. Hasil penelitian menunjukkan bahwa kesenjangan Servqual sebagian besar bernilai negatif dan terdapat satu atribut pelayanan yang masuk kuadran A (Underact). Namun hal ini tidak mutlak menunjukkan kualitas pelayanan frontliner Bank X kantor cabang khusus Sudirman masih rendah. 
Dari hasil analisis kesenjangan (gap) Servqual, walaupun nilai rata-rata gap semua dimensi pelayanan bernilai negatif, nilai rata-rata persepsi per butir sebagian besar mencapai nilai empat (4) dan nilai selisih antara persepsi dan harapan tidak terlalu besar. Begitu juga dengan hasil analisis IPA dan persebarannya di diagram kartesius, hanya ada satu atribut pelayanan yang termasuk dalam prioritas perbaikan. Dalam bagian pembahasan karakteristik responden, nasabah juga menjawab lebih memilih Bank X sebagai bank utama ketimbang bank lainnya. Hal ini menunjukkan bahwa persepsi nasabah atas kualitas pelayanan frontliner Bank X kantor cabang khusus Sudirman sebetulnya sudah baik, namun karena mayoritas nasabah berasal dari kelompok dengan aspirasi yang tinggi (dilihat dari mayoritas responden yang berprofesi sebagai pegawai swasta, berpenghasilan di atas lima juta rupiah dan berpendidikan sarjana), nasabah Bank X kantor cabang khusus Sudirman mempunyai ekspektasi yang lebih tinggi dibandingkan nasabah pada umumnya.

\section{KESIMPULAN DAN SARAN}

\section{Kesimpulan}

Hasil analisis gap dalam analisis Servqual menunjukkan harapan nasabah lebih tinggi daripada persepsi nasabah namun hal ini tidak berarti pelayanan frontliner Bank X kantor cabang khusus Sudirman berkualitas rendah. Keseluruhan nasabah yang menjadi responden menjawab lebih memilih Bank X sebagai bank utama walaupun mereka juga memiliki rekening di bank lain. Selain itu, persebaran atribut pelayanan di diagram kartesius terkonsentrasi di kuadran B (maintain) dan $\mathrm{C}$ (low priority) menunjukkan dari sisi nasabah bahwa pelayanan sudah berkinerja baik dan pihak bank telah mengalokasikan waktu dan tenaga di atribut pelayanan yang tepat. Karakteristik responden yang menunjukkan bahwa nasabah Bank X cabang khusus kantor Sudirman sebagian besar berprofesi sebagai pekerja swasta, berpendidikan terakhir sarjana, dan berpenghasilan di atas lima juta rupiah tentu mempunyai aspirasi dan tuntutan yang lebih tinggi dibanding nasabah pada umumnya sehingga ekspektasi terhadap pelayanan yang diterima pun lebih besar. Menurut nasabah, hanya ada satu atribut pelayanan yang perlu diperbaiki karena berada di kuadran A (underact) yaitu kecepatan staf dalam melayani. Hal ini sesuai dengan frekuensi kedatangan nasabah ke kantor front office yang sangat sering (sebulan sekali) sehingga peningkatan kecepatan pelayanan menjadi hal krusial untuk membuat pengalaman nasabah yang lebih positif lagi.

\section{Saran}

Pihak manajemen hendaknya mempertahankan kualitas pelayanan yang ada seperti sarana dan prasarana bank, sikap professional staf frontliner sehingga pengalaman positif nasabah dapat dipertahankan. Disarankan untuk pihak manajemen agar senantiasa aktif dalam memantau proses pelayanan frontliner agar SOP (standard of procedure) terpenuhi sehingga pelayanan yang maksimal dapat tercapai. Selain itu, CIP atau Continuous Improvement Process dapat dipraktikkan untuk mengembangkan pelayanan yang dapat memenuhi ekspetasi nasabah yang tinggi. Selain dari feedback nasabah seperti survey dan wawancara, masukan dari staf frontliner atas usaha pengembangan pelayanan juga sangat berguna untuk memastikan bahwa visi pegawai sejalan dengan visi perusahaan. Kecepatan pelayanan dapat ditingkatkan dengan instalasi sistem self-service di area bank. Sistem ini memungkinkan nasabah untuk melakukan beberapa transaksi secara mandiri, seperti membuka dan aktivasi tabungan sendiri, penarikan dan setor tunai, dan lainlain. Sistem self-service dapat memotong waktu nasabah untuk mengantri sehingga nasabah tidak perlu menunggu lama lagi untuk dilayani.

Saran untuk penelitian selanjutnya adalah untuk mencoba membahas kualitas pelayanan bagian bank selain frontliner. Bagian bank lain ini bisa seperti bagian back office yang bertugas mengurus dokumen atau bagian marketing. Selain itu, lokasi penelitian selanjutnya dapat dilakukan di kantor cabang Bank $\mathrm{X}$ di lokasi yang berbeda seperti di daerah pedesaan atau pinggiran kota untuk melihat variasi karakteristik nasabah di lokasi tersebut.

\section{DAFTAR PUSTAKA}

[BRI]. Nielsen AC. 2017. Understanding customer switching behavior "nasabah tabungan BRI" tahun 2017 oleh AC Nielsen. [data internal].

[BRI]. Morgan R. 2017. Customer switching behavior tahun 2016 oleh Roy Morgan. [data internal]. 
Adiningsih KP et al. 2015. Customer satisfaction and loyalty of a franchise product evidence from nasi bebek ginyo restaurant in Jakarta. Indonesian Journal of Business and Entrepreneurship $1(1): 42-50$.

Baroroh F. 2014. Evaluasi kepuasan konsumen terhadap pelayanan kefarmasian di Apotek Kota Yogyakarta. Pharmaçiana 4(2):135-141.

Despriyatmoko, Syarief R, Maulana A. 2016. Tingkat kepuasan terhadap kualitas pelayanan pemeliharaan pendaftaran tanah di kantor pertanahan Kabupaten Bogor. Jurnal Aplikasi Bisnis dan Manajemen 2(2):172-182.

Grönroos C. 2007. Service Management and Marketing: managing the moments of Truth in Service Competition. Ed. Ke-3. US: John Wiley.

Hair JF, Black WC, Babin, Anderson RE, Tatham RL. 2010. Multivariate Data Analysis. Ed. Ke-7. US: Prentice Hall.

Hutapea P, Thoha N. 2008. Kompetensi Plus: Teori, Desain, Kasus dan Penerapan untuk HR dan Organisasi yang Dinamis. Jakatarta: PT. Gramedia Pustaka Utama.

Kotler P. 2011. Manajemen Pemasaran: Analisis Perencanaan, Implementasi dan Pengendalian. Ed. Ke-13. Jakarta: Erlangga.

Malhotra NK, Dash S. 2016. Marketing Research: An Applied Orientation. Ed. Ke-7. US: Pearson.

Ong JO, Pambudi J. 2014. Analisis kepuasan pelanggan dengan important performance analysis di SBU Laboratory Cibitung PT Sucofindo (Persero). J@TI Undip 9(1):1-10.

Paramitasari N. 2016. Analisis kualitas pelayanan jasa menggunakan metode servqual di bagian penerimaan mahasiswa baru Institut Formatika dan Bisnis Darmajaya Bandar Lampung. Jurnal Manajemen Magister 2(1):83-94.

Phiri MA, Mcwabe T. 2013. Customers' expectation and perceptions of service quality; the case of pick $n$ pay supermarket stores in Pietermaritzburg area. Afrika Selatan. International Journal of Research in Social Sciences 3(1): 96-104.

Pratiwi D, Wahyono D, Sampurno. 2013. Analisis kepuasan pasien farmasi rawat jalan menggunakan metode servqual: studi di rumah sakit swasta X Jakarta. Jurnal Manajemen dan
Pelayanan Farmasi 3(1):24-29.

Sekaran B. 2013. Research Methods for Business: A Skill Building Approach, Ed. Ke-5. US: John Wiley.

Sofyan M. 2016. Analisis Kepuasan Masyarakat Kota dan Kabupaten Mojokerto Terhadap Proyek Pengendalian Banjir Perkotaan dengan Metode Importance Performance. Eksekutif: Jurnal Nasional Manajemen Bisnis 13(2):320-329.

Sutomo, Najib M, Djohar S. 2017. Pengaruh kualitas pelayanan lembaga Amil Zakat (LAZ) terhadap kepuasan dan loyalitas Muzakki (studi kasus LAZ PKPU Yogyakarta. Jurnal Aplikasi Bisnis dan Manajemen 3(1):59-70.

Syukri SHA. 2014. Penerapan customer satisfaction index (CSI) dan analisis gap pada kualitas pelayanan trans jogja. Jurnal Ilmiah Teknik Industri 13(2): 103-111.

Tarmoezi, Trizno, Manurung. 2000. Hotel Front Office. Jakarta: Kesaint Blanc.

Wijaya H, Beik IS, Sartono B. 2017. Pengaruh Kualitas Layanan Perbankan Terhadap Kepuasan dan Loyalitas Nasabah Bank Syariah XYZ di Jakarta. Jurnal Aplikasi Bisnis dan Manajemen 3(3): 417-426.

Windyani AR, Hubeis AV, Fahmi I. 2011. Analisis kepuasan masyarakat terhadap pembuatan akta kelahiran di Depok, Jawa Barat. Jurnal Aplikasi Manajemen 12(1):32-40.

Wiramanggala J, Firdaus M, Sasongko H. 2017. Persepsi lurah mengenai faktor-faktor yang memengaruhi kelurahan dalam pemungutan PBB P2. Jurnal Aplikasi Bisnis dan Manajemen 3(1):113-122.

Wong MS, Hideki N, George P. 2011. The use of importance-performance analysis (IPA) in evaluating japan's e-government services. Journal of Theoretical and Applied Electronic Commerce Research 6(2):17-30.

Yulia PR, Baga ML, Djohar S. 2016. Kepuasan konsumen terhadap pelayanan apotek dan tingkat pengetahuan konsumen mengenai standar pelayanan kefarmasian yang berlaku (studi kasus di Kota Depok). Jurnal Aplikasi Bisnis dan Manajemen 2(3):312-322. 